\title{
Pengaruh Kualitas Layanan terhadap Loyalitas Pelanggan Bamboo Coffee dan Resto di Lhokseumawe
}

\author{
Amanda Rizkillah \\ Fakultas Ekonomi dan Bisnis Islam (FEBI) IAIN Lhokseumawe \\ Amandarizki867@gmail.com \\ Suryani \\ Fakultas Ekonomi dan Bisnis Islam (FEBI) IAIN Lhokseumawe \\ Email: suryapijar@yahoo.com \\ Rahmawati \\ Fakultas Ekonomi dan Bisnis Islam (FEBI) IAIN Lhokseumawe \\ zidnirahma@gmail.com
}

\begin{abstract}
Bambo coffee and Resto become a restaurant that is great demand because it serves a variety of menu choices that continue to improve the quality of service to stay afloat and compete. This study discusses analyzing how to affect service quality on customer loyalty in Bamboo Coffee and Resto in Lhokseumawe. The sampling technique used was accidental sampling with a total sample of 94 consumers and multiple regression analysis as a data analysis technique. SERVQUAL Theory is a theory used to measure the quality of services, namely the dimensions of reliability (X1), responsiveness (X2), guarantee (X3), empathy (X4) and tangible (X5). The results of this study indicate the facts both simultaneously and simultaneously, this dimension has a very significant influence on customer loyalty.
\end{abstract}

Keywords: Service Quality, Customer Loyalty, Bamboo Coffee and Resto.

Abstrak

Bamboo Coffee dan Resto menjadi sebuah restoran yang banyak diminati karena menyajikan berbagai menu pilihan yang terus berupaya meningkatkan kualitas pelayanan untuk tetap bisa bertahan dan bersaing. Penelitian ini berfokus menganalisis bagaimana pengaruh kualitas pelayanan terhadap loyalitas pelanggan pada Bamboo Coffee dan Resto di Lhokseumawe. Teknik pengambilan sampel yang digunakan ialah accidental sampling dengan jumlah sampel yang diambil ialah sebanyak 94 konsumen dan analisis regresi berganda sebagai teknik analisis data. Teori SERVQUAL ialah teori yang digunakan untuk mengukur kualitas dari jasa, yaitu dengan dimensi reability $\left(\mathrm{X}_{1}\right)$, responsiveness $\left(\mathrm{X}_{2}\right)$, assurance $\left(\mathrm{X}_{3}\right)$, empathy $\left(\mathrm{X}_{4}\right)$ dan tangible $\left(\mathrm{X}_{5}\right)$. Hasil penelitian ini menunjukkan bahwa baik secara parsial maupun simultan, kelima dimensi tersebut mempunyai pengaruh yang sangat signifikan terhadap loyalitas pelanggan.

Kata Kunci: Kualitas Layanan, Loyalitas Pelanggan, Bamboo Coffee dan Resto.

\section{Pendahuluan}

Pelayanan merupakan suatu kegiatan yang dilakukan untuk kepentingan orang lain. Pelayanan merupakan faktor utama dalam mengembangkan suatu bisnis dan pelayanan itu pun menjadi jalan penghubung antara usaha tersebut dan para konsumen. Pelayanan memiliki hubungan erat dengan loyalitas konsumen. Pelayanan menjadi faktor utama seorang pelanggan menjalin hubungan yang erat, bukan hanya sekedar melayani namun untuk membangun suatu kerja sama jangka panjang dengan prinsip saling menguntungkan. Hasil penelitian Idfah Darusman (2015) menunjukkan bahwa pelayanan merupakan suatu kebutuhan yang seharusnya selalu dijaga dan ditingkatkan untuk menunjang perkembangan suatu usaha. Adanya pelayanan yang baik, maka akan menghasilkan pelanggan yang loyal pada tempat tersebut.

Loyalitas pelanggan adalah keadaan yang menunjukkan loyalnya seseorang pelanggan pada suatu objek tertentu. Sukarno Wibowo dkk (2011) mengatakan bahwa loyalitas pelanggan 
adalah salah satu variabel yang sangat penting karena loyalitas pelanggan akan sangat mempengaruhi laba perusahaan melalui efek dari pengurangan biaya dan penambahan pendapatan pelanggan. Sikap pelanggan yang loyal akan memberikan banyak keuntungan bagi perusahaan, karena semakin bagus loyalitas yang dibangun anatara perusahaan dan konsumen maka pelanggan akan melakukan pembelian kembali dan juga akan merekomendasikan kepada teman-temannya.

Michael R. Solomon (2010) mengatakan bahwa teori yang akan dipakai untuk melihat sebesar mana pengaruh kualitas layanan terhadap loyalitas pelanggan adalah Teori SERVQUAL. Teori ini merupakan teori yang dipakai untuk melihat tingkat kualitas pelayanan jasa. Beberapa dimensi yang digunakan untuk mengukur kualitas jasa tersebut adalah Keandalan (Reliability), Ketanggapan (Responsiveness), Jaminan (Assurance), Empati (Empathy), Bukti Fisik (Tangibles). Lina Sari Situmeang (2017) dalam penelitiannya menerangkan bahwa konsumen akan menggunakan kelima dimensi kualitas untuk membentuk penilaian terhadap kulitas jasa yang merupakan dasar untuk membandingkan harapan dan persepsinya terhadap jasa.

Terdapat perbedaan pada variabel dependent dan independent yang digunakan pada penelitian sebelumnya, yaitu penelitian Feibe Permatasari Karundeng (2013) menunjukkan hasil penelitian bahwa kualitas layanan dan kepuasan berpengaruh secara signifikan terhadap loyalitas layanan, namun penelitian Lina Sari Situmeang (2017) menggunakan variabel yang berbeda yaitu kualitas layanan dan harga mempunyai pengaruh yang signifikan terhadap kepuasan konsumen, sedangkan lokasi tidak berpengaruh terhadap kepuasan konsumen. Penelitian yang dilakukan oleh Woro Wardikawati dkk (2013) menunjukkan bahwa nilai pelanggan dan kualitas pelayanan mempunyai pengaruh terhadap loyalitas pelanggan melalui kepuasan pelanggan. Ida Ayu Inten Surya Utami dkk (2015) memperoleh hasil bahwa kualitas layanan menggunakan teori SERVQUAL mempunyai pengaruh yang sifnifikan terhadap kepuasan pelanggan.

Penelitian yang dilakukan oleh Ari Susanto Wibowo (2013) menunjukkan bahwa harga, kualitas pelayanan dan nilai pelanggan berpengaruh terhadap kepuasan konsumen, sedangkan penelitian oleh Pamela Montung dkk (2015) memperlihatkan hasil bahwa kualitas produk, kualitas layanan dan persepsi harga berpengaruh terhadap kepuasan pelanggan. Luky Hermawan dkk (2015) mengatakan bahwa kualitas pelayanan berpengaruh terhadap kepuasan pelanggan. Penelitian oleh Mitha Destika Sari (2014) menggunakan teori SERVQUAL yang memperlihatkan bahwa kualitas layanan yang berupa variabel $X_{1}, X_{2}, X_{3}$ dan $X_{4}$ tidak berpengaruh terhadap loyalitas konsumen sedangkan $\mathrm{X}_{5}$ berpengaruh terhadap loyalitas konsumen.

Penelitian ini dilakukan dengan tujuan untuk mengetahui pengaruh kualitas layanan terhadap loyalitas pelanggan dengan menggunakan teori SERVQUAL karena mempertimbangkan adanya perbedaan dengan penelitian sebelumnya yang terletak pada subyek penelitian, walaupun tetap menggunakan objek atau variabel yang sama. 


\section{Tinjauan Pustaka}

Michael R. Solomon (2010) mengatakan bahwa teori yang akan dipakai untuk melihat sebesar mana Pengaruh Kualitas Layanan Terhadap Loyalitas Pelanggan adalah Teori SERVQUAL. Teori ini merupakan teori yang dipakai untuk melihat tingkat kualitas pelayanan jasa. Beberapa dimensi yang digunakan untuk mengukur kualitas jasa tersebut adalah Keandalan (Reliability), Ketanggapan (Responsiveness), Jaminan (Assurance), Empati (Empathy), Bukti Fisik (Tangibles). Lina Sari Situmeang (2017) dalam penelitiannya menerangkan bahwa konsumen akan menggunakan kelima dimensi kualitas untuk membentuk penilaian terhadap kulitas jasa yang merupakan dasar untuk membandingkan harapan dan persepsinya terhadap jasa.

Terdapat perbedaan pada variabel dependent dan independent yang digunakan pada penelitian sebelumnya, yaitu penelitian Feibe Permatasari Karundeng (2013) menunjukkan hasil penelitian bahwa kualitas layanan dan kepuasan berpengaruh secara signifikan terhadap loyalitas layanan, namun penelitian Lina Sari Situmeang (2017) menggunakan variabel yang berbeda yaitu kualitas layanan dan harga mempunyai pengaruh yang signifikan terhadap kepuasan konsumen, sedangkan lokasi tidak berpengaruh terhadap kepuasan konsumen. Penelitian yang dilakukan oleh Woro Wardikawati dkk (2013) menunjukkan bahwa nilai pelanggan dan kualitas pelayanan mempunyai pengaruh terhadap loyalitas pelanggan melalui kepuasan pelanggan. Ida Ayu Inten Surya Utami dkk (2015) memperoleh hasil bahwa kualitas layanan menggunakan teori SERVQUAL mempunyai pengaruh yang sifnifikan terhadap kepuasan pelanggan.

Penelitian yang dilakukan oleh Ari Susanto Wibowo (2013) menunjukkan bahwa harga, kualitas pelayanan dan nilai pelanggan berpengaruh terhadap kepuasan konsumen, sedangkan penelitian oleh Pamela Montung dkk (2015) memperlihatkan hasil bahwa kualitas produk, kualitas layanan dan persepsi harga berpengaruh terhadap kepuasan pelanggan. Luky Hermawan dkk (2015) mengatakan bahwa kualitas pelayanan berpengaruh terhadap kepuasan pelanggan. Penelitian oleh Mitha Destika Sari (2014) menggunakan teori SERVQUAL yang memperlihatkan bahwa kualitas layanan yang berupa variabel $\mathrm{X}_{1}, \mathrm{X}_{2}, \mathrm{X}_{3}$ dan $\mathrm{X}_{4}$ tidak berpengaruh terhadap loyalitas konsumen sedangkan $\mathrm{X}_{5}$ berpengaruh terhadap loyalitas konsumen. Selanjutnya, penelitian yang dilakukan oleh Suwarsito dan Aliya (2020) menunjukkan hasil bahwa kualitas layanan dan kepuasan berpengaruh signifikan terhadap loyalitas pelanggan secara parsial dan secara simultan.

Penelitian ini dilakukan dengan tujuan untuk mengetahui pengaruh kualitas layanan terhadap loyalitas pelanggan dengan menggunakan teori SERVQUAL karena mempertimbangkan adanya perbedaan dengan penelitian sebelumnya yang terletak pada subyek penelitian, walaupun tetap menggunakan objek atau variabel yang sama.

\section{Metode Penelitian}

Pendekatan yang digunakan dalam penelitian ini ialah pendekatan kuantitatif dimana peneliti menggunakan analisis data yang berbentuk numeric/angka yang bertujuan untuk melakukan pengujian hipotesis sementara yang diajukan oleh si peneliti (Suryani dan Hendyadi, 2018). Populasi dalam penelitian ini ialah seluruh pelanggan pada Bamboo Coffee dan Resto di Lhokseumawe, sementara sampel penelitian yang di ambil oleh peneliti berjumlah 94 responden berdasarkan pendapat Hair bahwa untuk analisis regresi berganda, rasio sampel berkisar antara 15 hingga 20 pengamatan untuk setiap variabel prediktor (Hair et al., 2007). Variabel independen sebanyak 5 variabel yang dikalikan dengan jumlah keseluruhan item 
pertanyaan berjumlah 75, akan tetapi peneliti mampu mengumpulkan sebanyak 94 angket pada saat penyebaran angket/kuesior. Karakteristik utama responden yang menjadi sampel merupakan pelanggan pada Bamboo Coffee dan Resto tersebut denan tingkat pendidikan minimal SMP atau sederajat.

Objek penelitian ini ialah pengaruh kualitas layanan terhadap loyalitas pelanggan pada Bamboo Coffee dan Resto di Lhokseumawe. Data yang telah diperoleh kemudian diolah menggunakan program SPSS.

\section{Hasil dan Pembahasan}

\subsection{Karakteristik Responden}

Karakteristik responden dalam penelitian ini sebagian besar berjenis kelamin perempuan, mengingat perempuan lebih sering menjadikan tempat tersebut sebagai tempat untuk bersantai, baik dengan teman, pasangan maupun bersama keluarga, karena tempat tersebut menyediakan fasilitas yang baik. Responden yang berumur 20 tahun - 30 tahun merupakan responden yang lebih dominan dalam kategori umur dengan hasil yang diperoleh sebanyak $40 \%$ dari 94 responden sebagai sampel.

Kategori tingkat pendidikan terakhir menunjukkan hasil sebesar $38 \%$ untuk lulusan atau sedang belajar untuk tingkat pendidikan DIV, yang artinya pelanggan pada cafe tersebut lebih banyak dari tingkat pendidikan DIV dibanding dengan tingkat pendidikan yang lain. Frekuensi paling tinggi untuk karakteristik responden melalui pekerjaan jatuh kepada "wiraswasta" dengan jumlah persentase sebanyak 35\% dikarenakan pelanggan cafe tersebut tidak hanya berasal dari Lhokseumawe, namun juga berasal dari berbagai daerah di luar Lhokseumawe yang kebanyakan bekerja sebagai wiraswasta.

\subsection{Uji Validitas dan Reabilitas}

Hasil uji validitas menunjukkan bahwa keseluruhan indikator penelitian memiliki nilai korelasi diatas 0,30, dimana nilai korelasi terkecil sebesar 0,666 hingga nilai korelasi terbesar berjumlah 0,954 .

Hasil uji reabilitas menunjukkan nilai Cronbach's Alpha diatas 0,6 .pada setiap variabel, dimana nilai Cronbach's Alpha terkecil sebesar 0,837 hingga terbesar yaitu 0.895. dari hasil uji tersebut dapat disimpulkan bahwa instrumen penelitian dikatakan valid dan reliable sehingga dapat digunakan terhadap seluruh responden penelitian.

\subsection{Hasil Uji Asumsi Klasik}

\subsubsection{Uji Normalitas}

Hasil uji normalitas melalui analisis One-Sample Kolmogorov-Smirnov Test menunjukkan nilai Asymp. Sig. sebesar 0,786 lebih besar dari tingkat kekeliruan yaitu 5\% (0,05), yang dapat disimpulkan bahwa model regresi memenuhi asumsi normalitas.

\subsubsection{Uji Heteroskedasitas}

Hasil uji glejser menunjukkan bahwa tingkat signifikansi tiap variabel lebih besar dari 0,05 sehingga dapat dikatakan bahwa model regresi penelitian tidak terjadi heteroskedasitas. 
Tabel 1. Uji Heteroskedasitas

\begin{tabular}{|c|c|c|c|c|c|}
\hline \multirow[t]{2}{*}{ Model } & \multicolumn{2}{|c|}{$\begin{array}{l}\text { Unstandardized } \\
\text { Coefficients }\end{array}$} & $\begin{array}{l}\text { Standardized } \\
\text { Coefficients }\end{array}$ & \multirow[t]{2}{*}{$\mathrm{t}$} & \multirow[t]{2}{*}{ Sig. } \\
\hline & $\mathrm{B}$ & Std. Error & Beta & & \\
\hline (Constant) & 1.240 & .384 & & 3.232 & .002 \\
\hline Reliable & -.003 & .018 & -.023 & -.192 & .848 \\
\hline Responsiveness & -.009 & .019 & -.066 & -.459 & .647 \\
\hline Assurance & .006 & .023 & .041 & .278 & .781 \\
\hline Emphaty & -.011 & .021 & -.067 & -.520 & .604 \\
\hline Tangible & -.002 & .017 & -.016 & -.124 & .902 \\
\hline
\end{tabular}

Sumber: Olah Data SPSS 2020

\subsubsection{Uji Multikolenieritas}

Hasil uji multikolenearitas menunjukkan bahwa nilai tolerance variabel bebas diatas $10 \%(0,1)$ dan nilai VIF berada dibawah 10. Jadi dapat disimpulkan bahwa tidak ada multikolinieritas antar variabel bebas dalam model regresi.

Tabel 2. Multikolinieritas Coefficientsa

\begin{tabular}{|c|c|c|c|c|c|c|c|c|}
\hline \multirow{2}{*}{\multicolumn{2}{|c|}{ Model }} & \multicolumn{2}{|c|}{$\begin{array}{l}\text { Unstandardize } \\
\text { d Coefficients }\end{array}$} & \multirow{2}{*}{\begin{tabular}{|c}
$\begin{array}{c}\text { Standardize } \\
\mathrm{d} \\
\text { Coefficient } \\
\mathrm{s}\end{array}$ \\
Beta
\end{tabular}} & \multirow[t]{2}{*}{$\mathrm{t}$} & \multirow[t]{2}{*}{ Sig. } & \multicolumn{2}{|c|}{$\begin{array}{c}\text { Collinearity } \\
\text { Statistics }\end{array}$} \\
\hline & & B & $\begin{array}{l}\text { Std. } \\
\text { Error }\end{array}$ & & & & $\begin{array}{l}\text { Toleran } \\
\text { ce }\end{array}$ & VIF \\
\hline \multirow{6}{*}{1} & (Constant) & $\begin{array}{r}12.00 \\
0\end{array}$ & .653 & & $\begin{array}{r}18.36 \\
9\end{array}$ & .000 & & \\
\hline & Reliable & .063 & .031 & .127 & 2.070 & .041 & .801 & 1.249 \\
\hline & $\begin{array}{l}\text { Responsiven } \\
\text { ess }\end{array}$ & .117 & .033 & .265 & 3.556 & .001 & .545 & 1.836 \\
\hline & Assurance & .219 & .040 & .425 & 5.525 & .000 & .512 & 1.951 \\
\hline & Emphaty & .110 & .035 & .208 & 3.116 & .002 & .683 & 1.464 \\
\hline & Tangible & .062 & .028 & .143 & 2.166 & .033 & 699 & 1.430 \\
\hline
\end{tabular}

Sumber: Olah Data SPSS 2020

\subsubsection{Uji Autokorelasi}

Uji autokorelasi dilakukan melalui uji run testyang menunjukkan hasil dari Unstandarding ed Residual untuk nilai Asymp. Sig. (2-tailed) bernilai $0.213>0,05$, maka dapat disimpulkan bahwa tidak ada korelasi dari positif atau tidak ada masalah autokorelasi. 
Tabel 3. Autokorelasi Runs Test

\begin{tabular}{|l|r|}
\hline & \multicolumn{1}{|c|}{ Unstandardized Residual } \\
\hline Test Value & .01108 \\
Cases < Test Value & 47 \\
Cases >= Test Value & 47 \\
Total Cases & 94 \\
Number of Runs & 42 \\
Z & -1.244 \\
Asymp. Sig. (2-tailed) & .213 \\
\hline
\end{tabular}

Sumber: Olah Data SPSS, 2020

\subsection{Uji Hipotesis}

\subsubsection{Hasil Uji Koefisien Determinan $\left(\mathbf{R}^{2}\right)$}

Berdasarkan hasil uji koefisien korelasi menunjukkan bahwa besar koefisien determinan adjusted $R$ square atau kemampuan variabel independen dalam menjelaskan atau memprediksi variabel dependen sebesar 0,718 atau $71,8 \%$ maka dari $100 \%$ hanya $28,9 \%$ dipengaruhi variabel lainnya. Hal ini berarti variabel-variabel independen belum cukup memberikan informasi yang dibutuhkan untuk memprediksi variabel dependenya atau diprediksikan oleh faktor lain di luar variabel independen.

\section{Tabel 4. Koefisien Determinan $\left(\mathbf{R}^{2}\right)$ Model Summaryb}

\begin{tabular}{|l|l|r|r|r|}
\hline Model & R & R Square & Adjusted R Square & Std. Error of the Estimate \\
\hline 1 & $.856^{\mathrm{a}}$ & .733 & .718 & 1.199 \\
\hline
\end{tabular}

Sumber: Olah Data SPSS, 2020

\subsection{Hasil Uji F, Uji t dan Analisis Regresi Linear Berganda}

\subsubsection{Uji F}

Uji simultan ini bertujuan untuk menguji atau mengkonfirmasikan hipotesis yang menjelaskan tentang apakah reliable, Responsiveness, assurance, emphaty, dan tangible secara simultan berpengaruh terhadap loyalitas konsumen. Uji $\mathrm{F}$ ini dilakukan dengan membandingkan nilai $\mathrm{F}_{\text {hitung }}$ dengan $\mathrm{F}_{\text {tabel. }}$

Berdasarkan hasil perhitungan didapatkan $\mathrm{F}$ hitung sebesar 48.403 dengan tingkat signifikan

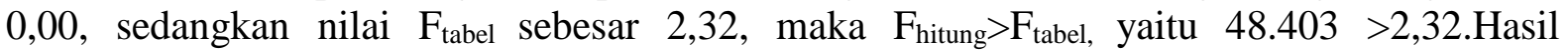
pengolahan data di atas menunjukkan bahwa $F_{h i t u n g}>F_{\text {tabel }}$ artinya faktor reliable, Responsiveness, assurance, emphaty, dan tangible secara simultan berpengaruh terhadap loyalitas konsumen pada Bamboo Coffe dan Resto. 
Tabel 5. Uji F ANOVAa

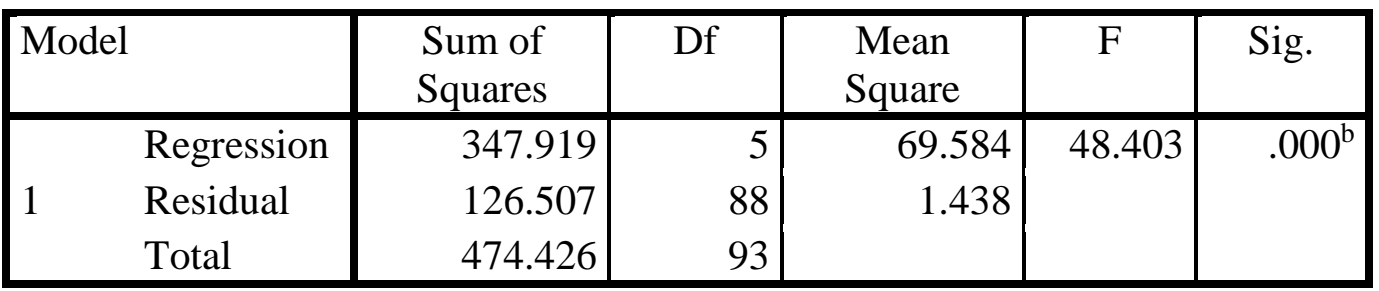

Sumber: Olah Data SPSS, 2020

\subsubsection{Uji t}

Uji secara parsial dilakukan untuk mengetahui apakah variabel bebas berpengaruh positif terhadap variabel terikat yang dilihat dari hasil regresi linier berganda.

\section{Tabel 6. Uji t}

\begin{tabular}{|c|c|c|c|c|c|}
\hline \multirow[t]{2}{*}{ Model } & \multicolumn{2}{|c|}{$\begin{array}{l}\text { Unstandardized } \\
\text { Coefficients }\end{array}$} & $\begin{array}{l}\text { Standardized } \\
\text { Coefficients }\end{array}$ & \multirow[t]{2}{*}{$\mathrm{T}$} & \multirow[t]{2}{*}{ Sig. } \\
\hline & $\mathrm{B}$ & $\begin{array}{l}\text { Std. } \\
\text { Error }\end{array}$ & Beta & & \\
\hline \multirow{6}{*}{$\begin{array}{l}\text { (Constant) } \\
\text { Reliable } \\
\text { Responsiveness } \\
\text { Assurance } \\
\text { Emphaty } \\
\text { Tangible }\end{array}$} & 12.000 & .653 & & 18.369 & .000 \\
\hline & .063 & .031 & .127 & 2.070 & .041 \\
\hline & .117 & .033 & .265 & 3.556 & .001 \\
\hline & .219 & .040 & .425 & 5.525 & .000 \\
\hline & .110 & .035 & .208 & 3.116 & .002 \\
\hline & .062 & .028 & .143 & 2.166 & .033 \\
\hline
\end{tabular}

Sumber: Olah Data SPSS, 2020

Dilihat dari tabel di atas, data menunjukkan bahwa semua variabel bebas terdapat hubungan terhadap variabel terikat secara parsial dan signifikan yaitu:

a. Pengaruh Reliable (X1) terhadap loyalitas (Y)

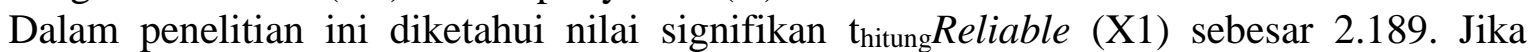
dibandingkan dengan nilai $t_{\text {tabel }}=\frac{0,05}{2} ; 94-5-1=0,025 ; 88=1,987$ maka $t_{\text {hitung }}>t_{\text {tabel }}=$ $2.070>1,987$ Dengan demikian berpengaruh positif dan signifikan karena 0,041<0,05 terhadap loyalitas maka $\mathrm{Ha}_{1}$ terbukti/diterima.

b. Pengaruh Responsiveness (X2) loyalitas (Y)

Dalam penelitian diketahui nilai signifikan thitung Responsiveness (X2) sebesar 3.556 Jika dibandingkan dengan nilai $t_{\text {tabel }}=1,987$ maka $t_{\text {hitung }}>t_{\text {tabel }}=3.556>1,987$ Dengan demikian berpengaruh positif dan signifikan karena 0,001 $<0,05$ terhadap loyalitas maka $\mathrm{Ha}_{2}$ terbukti/diterima.

c. Pengaruh assurance (X3) loyalitas (Y)

Dalam penelitian ini diketahui nilai signifikan $t_{\text {hitung }}$ assurance (X3) sebesar 5.525. Jika dibandingkan dengan nilai $t_{\text {tabel }}=1,987$ maka $t_{\text {hitung }}>t_{\text {tabel }}=5.525>1,987$. Dengan demikian berpengaruh positif dan signifikan karena $0,000<0,05$ terhadap loyalitas maka $\mathrm{Ha}_{3}$ terbukti/diterima.

d. Pengaruh emphaty (X3) loyalitas (Y) 
Dalam penelitian ini diketahui nilai signifikan $t_{\text {hitungemphaty }}$ (X3) sebesar 3.116. Jika dibandingkan dengan nilai $t_{\text {tabel }}=1,987$ maka $t_{\text {hitung }}>t_{\text {tabel }}=3.116>1,987$. Dengan demikian berpengaruh positif dan signifikan karena 0,002 <0,05 terhadap loyalitas maka $\mathrm{Ha}_{3}$ terbukti/diterima.

e. Pengaruh tangible (X3) loyalitas (Y)

Dalam penelitian ini diketahui nilai signifikan thitung tangible (X3) sebesar 2.166. Jika dibandingkan dengan nilai $t_{\text {tabel }}=1,987$ maka $t_{\text {hitung }}>t_{\text {tabel }}=2,166>1,987$. Dengan demikian berpengaruh positif dan signifikan karena $0,033<0,05$ terhadap loyalitas maka $\mathrm{Ha}_{3}$ terbukti/diterima.

Berdasarkan hasil perhitungan di atas, maka dapat diketahui bahwa seluruh variabel bebas mempengaruhi variabel terikat yaitu variabel faktor reliable, Responsiveness, assurance, emphaty, dan tangible dengan didapatkannya nilat $t_{\text {hitung }}>t_{\text {tabel }}$ yang positif dan nilai probabilitas singnifikan $<$ dari 0,05 dan positif.

\subsection{Analisis Regresi Linear Berganda}

Model regresi linear berganda diperoleh dari tabel 7 dengan rumus sebagai berikut:

$\mathrm{Y}=\alpha+b_{1} X_{1}+b_{2} X_{2}+b_{3} X_{3}+4 X_{4}+b_{5} X_{5}$

$Y=12.000+0.063 X_{1}+0,117 X_{2}+0,219 X_{3}+0,110 X_{4}+0,062 X_{5}$

Dimana :

\begin{tabular}{|c|c|}
\hline Y & $=$ Loyalitas Konsumen \\
\hline $\mathrm{a}$ & $=$ Konstanta \\
\hline $\mathrm{X}_{1}$ & $=$ Reliable \\
\hline $\mathrm{X}_{2}$ & $=$ Responsiveness \\
\hline $\mathrm{X}_{3}$ & $=$ Assurance \\
\hline $\mathrm{X}_{4}$ & $=$ Emphaty \\
\hline $\mathrm{X}_{5}$ & $=$ Tangible \\
\hline $\mathrm{b}_{1}, \mathrm{~b}_{2}, \mathrm{~b}_{3}, \mathrm{~b}_{4}, \mathrm{~b}_{5}$ & $=$ Koefisien Regresi \\
\hline $\mathrm{e}$ & $=$ Kesalahan Pengganggu (standar error). \\
\hline $\mathrm{b}$ & $=$ lereng garis yang berkaitan dengan variabel $\mathrm{X}$ \\
\hline
\end{tabular}

Koefisien-koefisien pada persamaan regresi linier berganda di atas dapat diartikan sebagai berikut:

i. Nilai konstanta model persamaan regresi adalah sebesar 12.000 artinya jika variabelvariabel X1, X2, X3, X4 dan X5 bernilai nol, maka rata-rata loyalitas konsumen adalah sebesar 12.000 .

ii. Nilai koefisien regresi Reliable dari dalam sebesar 0.063. Hal ini menunjukkan bahwa setiap peningkatan sebesar $1 \%$ satuan, maka loyalitas konsumen akan naik sebesar $6,3 \%$. Sebaliknya jika loyalitas konsumen mengalami penurunan sebesar $1 \%$ satuan maka Reliable akan menurun sebesar 6,3\%. Hal ini menunjukkan bahwa antara Reliable dan loyalitas konsumen menunjukkan hubungan yang positif.

iii. Nilai koefisien regresi Responsiveness sebesar 0,117. Hal ini menunjukkan bahwa setiap peningkatan sebesar $1 \%$ satuan, maka loyalitas konsumen akan naik $11,7 \%$. Sebaliknya jika loyalitas konsumen mengalami penurunan sebesar 1\% satuan maka Responsiveness akan menurun sebesar $11,7 \%$. Hal ini menunjukkan bahwa antara Responsiveness dan loyalitas konsumen menunjukkan hubungan yang positif. 
iv. Nilai koefisien regresi assurance sebesar 0,219. Hal ini menunjukkan bahwa setiap peningkatan sebesar 1\% satuan, maka loyalitas konsumen akan naik sebesar 21,9\%. Sebaliknya jika loyalitas konsumen mengalami penurunan sebesar $1 \%$ satuan maka assurance akan menurun sebesar 21,9\%. Hal ini menunjukkan bahwa antara assurance dan loyalitas konsumen menunjukkan hubungan yang positif.

v. Nilai koefisien regresi emphaty sebesar 0,110. Hal ini menunjukkan bahwa setiap peningkatan sebesar $1 \%$ satuan, maka loyalitas konsumen akan naik sebesar $11 \%$. Sebaliknya jika loyalitas konsumen mengalami penurunan sebesar 1\% satuan maka emphaty akan menurun sebesar $11 \%$. Hal ini menunjukkan bahwa antara emphaty dan loyalitas konsumen menunjukkan hubungan yang positif.

vi. Nilai koefisien regresi tangible sebesar 0,062. Hal ini menunjukkan bahwa setiap peningkatan sebesar $1 \%$ satuan, maka loyalitas konsumen akan naik 6,2\%. Sebaliknya jika loyalitas konsumen mengalami penurunan sebesar $1 \%$ satuan maka tangible akan menurun sebesar 6,2\%. Hal ini menunjukkan bahwa antara tangibles dan loyalitas konsumen menunjukkan hubungan yang positif.

\section{Simpulan}

Berdasarkan hasil penelitian dapat disimpulkan bahwa:

1. Secara parsial Reliable berpengaruh positif dan signifikan terhadap Loyalitas konsumen pada Bamboo Coffe dan Resto itu terbukti dari nilai probabilitas signifikan $0,041<0,05$, serta dengan nilai $t_{\text {hitung }}>t_{\text {tabel }}(2,070>1,987)$.

2. Secara parsial Responsiveness berpengaruh positif dan signifikan terhadap Loyalitas konsumen pada Bamboo Coffe dan Resto itu terbukti dari nilai probabilitas signifikan $0,001<0,05$ serta dengan nilai $t_{\text {hitung }}>t_{\text {tabel }}(3.556>1,987)$.

3. Secara parsial assurance berpengaruh positif dan signifikan terhadap Loyalitas konsumen pada Bamboo Coffe dan Resto itu terbukti dari nilai probabilitas signifikan $0,000<0,05$ serta dengan nilai $t_{\text {hitung }}>\mathrm{t}_{\text {tabel }}(5.525>1,987)$.

4. Secara parsial emphaty berpengaruh positif dan signifikan terhadap Loyalitas konsumen pada Bamboo Coffe dan Resto itu terbukti dari nilai probabilitas signifikan $0,002<0,05$ serta dengan nilai $t_{\text {hitung }}>\mathrm{t}_{\text {tabel }}(3.116>1,987)$.

5. Secara parsial tangible berpengaruh positif dan signifikan terhadap Loyalitas konsumen pada Bamboo Coffe dan Resto itu terbukti dari nilai probabilitas signifikan $0,033<0,05$ serta dengan nilai $t_{\text {hitung }}>\mathrm{t}_{\text {tabel }}(2.166>1,987)$.

6. Secara simultan Faktor reliable, Responsiveness, assurance, emphaty, dan tangible berpengaruh positif dan signifikan terhadap Loyalitas konsumen pada Bamboo Coffe dan Resto, itu ternukti dari hasil penelitian didapatkan bahwa $F_{\text {hitung }}>F_{\text {tabel, yaitu }}$ 48,403> 2,32 dengan signifikan 0,000.

\section{Daftar Pustaka}

Darusman, Idfah. (2015). Analisis Pengaruh Kualitas Pelayanan Terhadap Loyalitas Pelanggan pada Apotek Dinda Farma Di Klaten. Surakarta: Universitas Muhammadiyah Surakarta. Skripsi dipublikasikan. Pdf.

Hair, J.F. (2007). Multivariate Data Analysis. Fifth Edition. New York: MacMillan Publishing Company. 
Hermawan, Luky dan Marheni Eka Saputri. (2014). Pengaruh Kualitas Layanan Terhadap Kepuasan Pelanggan pada Restoran Bebek H. Slamet Di Cabang Radio Dalam, Jakarta Selatan. Jakarta Selatan: Universitas Telkom.

Imam Ghozali. (2013). AplikasiAnalisis Multivariat dengan Program IBM SPSS 19. Edisi ke-5. Semarang: Universitas Diponegoro.

Karundeng, Feibe Permatasari. (2013). Kualitas Pelayanan dan KepuasanPengaruhnya terhadap Loyalitas Pelanggan pada Rumah Makan Sharron Wanea Manado”. Jurnal Ekonomi, Manajemen, Bisnis dan Akuntansi (EMBA). Vol. 1 No. 3.

Kasmir. (2005). Manajemen Perbankan. Jakarta: Rajawali.

Kotler, Philip dan Kevin Lane Keller. (2009). Manajemen Pemasaran Edisi 13 Jilid 1. Jakarta: Erlangga.

Montung, Pamela, Jantje Sepang dan Decky Adare. (2015). Pengaruh Kualitas Produk, Kualitas Layanan dan Persepsi Harga Terhadap Kepuasan Pelanggan di Restoran Kawan Baru. Jurnal Berkala Ilmiah Efisiensi, Volume 15, No. 05.

Sari, Mitha Destika. Pengaruh Kualitas Layanan Terhadap Loyalitas Konsumen pada Cafe D'Puncak Di Samarinda.

Situmeang, Lina Sari. (2017). Pengaruh Kualitas Pelayanan, Harga Dan Lokasi Terhadap Kepuasan Konsumen Pada Rumah Makan Istana HotPlate Medan. Medan: UIN Sumatera Utara.

Solomon, Michael R. (2010). Consumer Behavior, Ninth Edition.New Jersey: PearsonEducation.

Sugiono. (2007). Metode Penelitian Kuantitatif, Kualitatif dan $R$ \& D cet. III. Bandung: Alfabeta.

Suryani dan Hendryadi. (2016). Metode Riset Kuantitatif: Teori dan Aplikasi pada Bidang Manajemen dan Ekonomi Islam Cet. II. Jakarta: Prenadamedia Group.

Suwarsito, S., \& Aliya, S. (2020). Kualitas Layanan dan Kepuasan Serta Pengaruhnya Terhadap Loyalitas Pelanggan. Jurnal Ilmiah Bina Manajemen, 3(1), 27-35.

Tjiptono, Fandy. (2014). Pemasaran Jasa. Yogyakarta: CV. Andi Offset.

Utami, Ida Ayu Inten Surya dan I Made Jatra. (2015). Pengaruh Kualitas Layanan Terhadap Kepuasan Pelanggan Restoran Baruna Sanur di Bali. Bali: Universitas Udayana. E-Jurnal Manajemen Unud, Vol. 4, No. 7.

Wardikawati, Woro dan Naili Farida. (2013). Pengaruh Nilai Pelanggan dan Kualitas Layanan TerhadapLoyalitas Pelanggan, Melalui Kepuasan Pelanggan PadaPelanggan Bus Efisiensi(Studi Po Efisiensi Jurusan YogyakartaCilacap)". Jurnal Administrasi Bisnis, Volume 2, No. 1.

Wibowo, Ari Susanto. (2013). Pengaruh Harga, Kualitas Pelayanan dan Nilai Pelanggan Terhadap Kepuasan Konsumen pada Rumah Makan di Kota Purwokerto. Semarang: Universitas Negeri Semarang.

www.spssindonesia.com/2014/02/uji-heteroskedastisitas-glejser-spss/ 